\title{
NOMINALIZATION IN APPLIED LINGUISTICS AND MEDICINE: THE CASE OF TEXTBOOK INTRODUCTIONS AND BOOK REVIEWS
}

\author{
ALIREZA JALILIFAR \\ Shahid Chamran University of Ahvaz, Iran \\ ar.jalilifar@gmail.com
}

\section{SEYEDEH ELHAM ELHAMBAKHSH}

Shahid Chamran University of Ahvaz, Iran

e.elhambakhsh@gmail.com

\section{PETER R. White}

University of New South Wales, Australia

prr.white@unsw.edu.au

\begin{abstract}
Drawing on Systemic Functional Linguistics, this study explored variational use of nominalization in 600 textbook introductions and 200 book reviews in applied linguistics and medicine. The nominalized expressions were identified in the texts, the frequencies of the nominalization types were counted, and eventually a chi-square test was administered. Analysis of nominalization patterns across the different informational/promotional moves revealed divergent patterns in the two disciplines but insignificant differences across the genres in focus. The density of nominalizations was acknowledged in the applied linguistics introductions and book reviews. However, functional variations in the use of nominalizations were found only in the introductions. As for the proportion of nominalization to grammatical metaphor, results demonstrated a lower tendency towards nominalizing scientific information in the medicine corpus. Further research is needed to see how nominalization is exploited in other genres and other disciplines.
\end{abstract}

Keywords: book reviews, introduction, nominalization, systemic functional linguistics

\section{Introduction}

Over the last three decades, English for Specific Purposes (ESP) researchers have employed genre analysis extensively to examine a variety of academic genres including abstracts, presentations, lectures, theses, dissertations and textbooks and their related discourses (e.g., Bhatia, 1997, 2004; Bunton, 2002; Dudley-Evans, 1986; Hopkins and Dudley-Evans, 1988; Hyland, 2004; Hyon, 1996; Martin, Christie, and Rothery, 1987; Nwogu, 1997; Paltridge, 1997; Samraj, 2005; Swales, 2004; Thompson, 1994). While several studies have focused on 
disciplinary writing (e.g., Brett, 1994; Holmes, 1997; Kuteeva, 2013; McCloskey, 1986; Peck MacDonald, 1990, 1992), other studies have explored particular sections of the research article (RA) or its overall structure cross-linguistically (see e.g., Coffin, Curry, Goodman, Hewings, Lillis and Swann, 2003; Hyland, 2009; Marefat and Mohammadzadeh, 2013; Martin, 2003). Many of the above academic genres begin by an introduction section wherein authors lay down their points of argument.

Introductory genres, which are conventionally used to introduce academic research articles and textbooks and their various manifestations, distinctly named as introduction, foreword, preface, acknowledgement and, occasionally, trajectory, preamble or prologue, have received prime attention in recent years (e.g., Abdollahzadeh and Salarvand, 2013; Bhatia, 1997; Jalilifar and Golkar Moosavi, 2016; Kuhi, 2008; Sorayyaei Azar, 2012; Zepetnek, 2010). Research into academic introduction sections of textbooks has not been prolific. Bhatia (1997) presented book introductions and book prefaces as different categories of academic introductions, arguing that the former fulfills an informative function while the latter fulfills both a promotional and an informative one. He finally acknowledged that one other purpose of all academic introductions, as an example of an interested genre, seems to be promoting the work, which even sometimes takes precedence over the original purpose (i.e., introducing the work).

Book reviews (as another focus of this study), on the contrary, are considered as a sub-genre (Bhatia, 1993: 21) or a member of the family of review genres (Giannoni, 2009). In terms of communicative purposes, review genres vary along a continuum extending from the most promotional (arguably blurbs (Bhatia, 2004; Cacchiani, 2007; Gesuato, 2004)) to the most critical (e.g., expert reviews). In book reviews, the purpose switches from endorsement to criticism, as the reviewer is a (supposedly neutral) third party acting as a gatekeeper on behalf of the academic community (Giannoni, 2009: 19). Book reviews, as examples of a disinterested genre, are defined as promotional (Bhatia, 1997, 2002; Lorés-Sanz, 2012) and evaluative (e.g., Gea Valor, 2000-2001; Groom, 2009; Hyland, 2004; Lorés-Sanz, 2012; Römer, 2005, 2008; Shaw, 2004, 2009; Tse and Hyland, 2009; Vassileva, 2010) and are meant to act as critical windows which open to the novelties and advances of a given discipline, and, in that sense, they may well contribute to the construction and development of disciplinary knowledge.

Valuable works on book reviews and introductory genres have brought an insight into their macro-structures and linguistic analyses. These studies, however, vary in their foci from disciplinary and cross-disciplinary variations to crosslinguistic differences of these genres and their micro-structure features. Given the variations of the introductory sections of textbooks and the importance attached to them as well as their seemingly close relationship with book reviews in presentation of an overview of the textbooks, the absence of more comparative research on micro-linguistic features in this regard is especially prominent. The fact that book reviews and most of the introductory sections of academic textbooks share at least one communicative purpose, that is to introduce the book in focus, 
seemingly causes a considerable overlap, but some of them are sometimes appropriated by publishers to promote their product (Jalilifar and Golkar Moosavi, 2016).

It has been demonstrated that whereas textbook introductory sections seem to chiefly reinforce the positive aspects of the book, book reviews attend to both merits and demerits, looking at the book in focus with a critical mind from the outside (Alcaraz Ariza, 2010; Diani, 2007; Hyland, 2004; Hyland and Diani, 2009; Lindholm-Romantschuk, 1998; Motta-Roth, 1998; Salager-Meyer and Alcaraz Ariza, 2004). Given these functional differences, our assumption is that these aspects might partly transpire in the nominalizations used. Authors may experience confusion if they are not fully aware of genre tendencies and linguistic characteristics.

The inspiration for a comparative study of textbook introductions and book reviews comes from the need to determine how far the nominalization patterns are distinct in two disparate disciplines of applied linguistics and medicine, representing soft and hard sciences. There is, therefore, a pedagogical rationale for extending the analysis of the academic texts into a comparative study of nominalization use across two disciplines. The study hypothesizes that differences in nominalization use might become even more explicit when disciplinary tendencies also intervene, especially when the disciplines appear to be far from one another.

\section{Theoretical framework of the study}

This study is grounded in Halliday's (1994) systemic functional linguistics (SFL). SFL interprets language as interrelated sets of options for making meanings and seeks to provide a clear relationship between functions and grammatical systems (Halliday, 1994). Systemists focus on "how the grammar of a language serves as a resource for making and exchanging meanings" (Lock, 1996: 3). That is, SFL is concerned with the grammatical patterns and lexical items used in texts, as well as choices of those items. The grammatical domain of language is considered an important area of inquiry, an offshoot of which is studied under grammatical metaphor (Halliday, 1994). Grammatical metaphor is defined as "a substitution of one grammatical class, or one grammatical structure by another" (Halliday and Martin, 2005: 87). Specialized technical discourse cannot be created without deploying grammatical metaphor (Martin, 1990). In the area of grammatical metaphor, for any given semantic configuration, there will be some realization in the lexicogrammar-some wording - that can be considered congruent or unmarked; there may also be various others that are in some respect incongruent, "transferred" or "metaphorical" (Halliday, 1994: 342).

In SFL, nominalization is connected to grammatical metaphor used to indicate a process or an attribute. Halliday and Matthiessen (1999) categorize grammatical metaphor into 13 types of which four types are classified as nominalizations, in 
terms of semantic shifts involved in transforming the congruent into the incongruent form (i.e., adjective $>$ noun, verb $>$ noun, conjunction $>$ noun, and preposition (al phrase) $>$ noun).

As an aspect of complexity in written language (Halliday and Matthiessen, 2004; Heyvaert, 2003), nominalization is used for embedding as much information into a few words as possible. A nominalized structure like $I$ have found a lot of appreciation and greater acceptance abroad, for instance, is thus viewed as the metaphorical counterpart of the clause The scholars abroad have greatly appreciated and accepted the book. In order to fully grasp the meaning of nominalization as an additional dimension of meaning, the identification and the analysis of both the metaphorical and the congruent realizations are essential (Halliday, 1994; Heyvaert, 2003).

The use of nominalization in scientific discourse has been the subject of a wide array of studies in recent years, for example, the historical origins of nominalization in scientific discourse (Banks, 2005), the realization of grammatical metaphor in modern prose fiction (Farahani and Hadidi, 2008), the contribution of verb-based nominalization to cohesion in 892 pages of history texts (Susinskiene, 2009), nominalization in the writing of undergraduate students (Baratta, 2010), and the role of nominalization in the English medical papers produced by native English speakers and Chinese writers (Wenyan, 2012). Other studies on nominalization in scientific discourse (e.g., Banks, 2003; Baratta, 2010; Halliday and Matthiessen, 1999, 2004; Ho, 2010; Jalilifar, Alipoor and Parsa, 2014; Martin, 1993; Sušinskienè, 2009, 2010; Wenyan, 2012) have also stressed the crucial role played by nominalization in the skillful orchestration of academic discourse. In fact, considering the frequency and usage of different types of nominalization, research on nominalization indicates variation in abstracts and in research articles (Holtz, 2009), in British newspaper editorials (Sušinskiené, 2010), in essay writings of undergraduate students (Baratta, 2010), in request emails (Ho, 2010), in business letters (Văn, 2011), in the discussion sections of medical research articles (Wenyan, 2012). Yet, we doubt how nominalization is realized in textbooks introductions and book reviews across disciplines. In other words, it is not clear how nominalization use is related to typological similarities and differences between medicine and applied linguistics as examples of hard and soft applied sciences. Nevertheless, the realization between discipline specificity, text scientificity, and nominalization has yet to be adequately examined. Furthermore, an understanding of the functional role and textual consequences of grammatical metaphor is essential for a full understanding of the meaning of any text.

Notwithstanding the aforesaid studies on nominalization from various angles, further research is required to find out disciplinary and genre specificity in the use of nominalization. Thus, this study seeks to investigate the variational use of nominalization in applied linguistics and medicine textbook introductions, prefaces, forewords and in book reviews. The analysis of these texts involves four steps: The first step of analysis identifies the frequency of nominalized 
expressions and grammatical metaphors in each text. In the second step, different types of semantic shifts in the process of nominalization are determined. In the third step, the density of nominalization is examined. In th fourth step, the proportion of nominalization to grammatical metaphor in each genre is calculateded and the grammatical patterns of nominalization deployment are also illustrated in detail. Accordingly, the following questions stand out:

1. What are the grammatical functions of nominal expressions and their relative distributions in the sample English textbooks introduction sections and book reviews in applied linguistics and medicine, and how do the functions and their relative frequency of deployment compare?

2. What types of semantic shifts (i.e. quality, process, circumstance and relator) in the process of nominalization are frequently used in English applied linguistics and medicine textbooks introduction sections and book reviews, and how do the types and their relative frequencies compare?

3. Is there any significant difference in the density of nominalization use between English textbooks introduction sections and book reviews in applied linguistics and medicine?

4. What are the grammatical patterns of nominalization deployment and their relative distributions in the sample English textbooks introduction sections and book reviews in applied linguistics and medicine, and how do the patterns and their relative frequency of deployment compare?

\section{Method}

\subsection{Selection of the disciplines}

Following the experience of scientometricians and external experts, Glanzel and Schubert (2003) propose a two-level hierarchical classification scheme for three main discipline areas: Sciences, Social Sciences, and Humanities. Their two-level scheme includes 12 first-level fields and 60 second-level subfields of the Sciences, as well as three major fields and seven subfields for the Social Sciences and Humanities. Coffin, et al (2003) added one more major area—applied versus pure disciplines--and provided some representative examples for these four main discipline areas.

Acknowledging the complexity of demarcating disciplines, the present analysis rested on the most convenient way of grouping disciplines into four main areas: Sciences, Social Sciences, Humanities/Arts, and Applied Disciplines (Coffin, et al., 2003; Glanzel and Schubert, 2003). Figure 1 demonstrates a revision of Hyland's (2006) continuum, adding the hard applied seciences, which include disciplines such as medicine. 


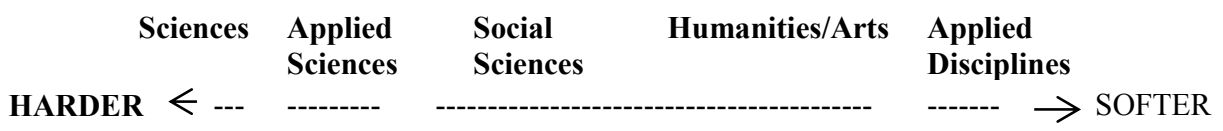

Figure 1. Continuum of disciplines (Revised)

Selection of the disciplines was motivated by the need to build a corpus representative of textbook introductions and book reviews in applied linguistics (closer to the soft end of the continuum) and medicine (closer to the hard end of the continuum). The motivation for selecting these disciplines as middle areas of science was to investigate representatives of two applied disciplines related to two major branches of science which can possess both similarities (due to the softer nature of applied disciplines) and differences (since each has a different tendency towards soft or hard sciences).

\subsection{Selection of the textbook introductions}

Three hundred English textbook introductions (100 samples from each variation of introduction, i.e., introduction, foreword, and preface) in each discipline were selected to allow comparisons across hard and soft applied sciences (a total of 600 samples). Textbook selection was to meet the following criteria:

i. The choice of textbooks was motivated by the need to control such variables as writer experience and expertise. The major criterion in selection was to include textbooks which were widely used in the syllabuses of applied linguistics and medicine courses in Iranian universities. Hence, a number of informants in each discipline were asked to recommend textbooks available in hard copies or those retrievable from downloadable databases that they considered as essential in their own field at two levels of BS/BA and $\mathrm{PhD}$.

ii. To ensure the validity of analysis, textbooks written in English by English speaking authors were preferred.

iii. The selected corpus represented a span of 10 years (i.e., textbooks published in 2006-2016). The assumption was that a genre might change and evolve in response to changes in the communicative goals, as well as to "particular rhetorical needs" of the discourse community that regularly uses it (Abdollahzadeh, 2013: 424).

\subsection{Selection of the book reviews}

With regard to the selection of book reviews, initially, a list of applied linguistics and medicine journals publishing English language papers in the two disciplines was compiled. The major criteria guiding the identification of journals, from which book reviews in the corpus were taken, were reputation, accessibility, representativeness and dominance of the journals based on their impact factors, as 
well as the period of publication of the book reviews. The criteria were shared with two independent applied linguistics experts and two independent medicine experts following panel discussions. The preliminary corpus for the pilot phase was drawn from the consented journals. The final corpus, consisting of 200 book reviews (100 from each discipline) was selected on the basis of stratified sampling procedure (see Table 1.). Similar to the introductions, selection of the reviews was restricted to a period of 10 years (2006-2016). Moreover, to qualify for the final corpus, all the book reviews had to be approximately 1000 words on average, to control length.

Table 1. Selected Journals in Medicine and Applied Linguistics

\begin{tabular}{lclc}
\hline $\begin{array}{c}\text { Applied Linguistics } \\
\text { Journals }\end{array}$ & $\begin{array}{c}\text { No. of } \\
\text { BRs }\end{array}$ & \multicolumn{1}{c}{$\begin{array}{c}\text { Medicine } \\
\text { Journals }\end{array}$} & $\begin{array}{c}\text { No. of } \\
\text { BRs }\end{array}$ \\
\hline $\begin{array}{l}\text { English for } \\
\text { Academic Purposes }\end{array}$ & 20 & British Medical Journal & 20 \\
$\begin{array}{l}\text { Second Language } \\
\text { Writing }\end{array}$ & 20 & $\begin{array}{l}\text { Annals of Otology, } \\
\text { Rhinology and } \\
\text { Laryngology } \\
\text { Annals of Medicine } \\
\text { and Surgery }\end{array}$ & 20 \\
Language Teaching & 20 & $\begin{array}{l}\text { Annals of Emergency } \\
\text { Medication }\end{array}$ & 20 \\
$\begin{array}{l}\text { Writing and } \\
\text { Pedagogy }\end{array}$ & 20 & $\begin{array}{l}\text { Asian Pacific Journal } \\
\text { of Tropical Medicine }\end{array}$ & 20 \\
$\begin{array}{l}\text { Studies in Second } \\
\text { Language } \\
\text { Acquisition }\end{array}$ & 20 & 167533 & \\
\hline
\end{tabular}

\subsection{Procedure}

Prior to analyzing the data, the unit of analysis was assigned to be the clause complex. Clause complexes show "how the flow of events is construed in the development of text at the level of semantics" (Halliday and Matthiessen, 2004: 63). Eggins (2004) defines clause complex (i.e., parataxis and hypotaxis) as a "grammatical and semantic unit formed when two or more clauses are linked together in certain systematic and meaningful way" (p. 255). The clauses were coded in each text and the texts were coded in each genre, for instance, Bp. Med. \#029 means text 029 which is a book preface in medicine. BI., BF., BR., and AL. stand for book introduction, book foreword, book review, and applied linguistics respectively.

One tricky and controversial category of nominals is gerunds. This study opts for consideration of gerunds denoting actions rather than situations as examples of verb $>$ noun nominalization. Following Simon-Vandenbergen, Taverniers and Ravelli (2003: 82-83), this study assumed that as long as the gerund form can be 
preceded by a premodifier, such as that of a possessive pronoun, it can be categorized as a nominal. However, in case the gerund only denotes modality, tense or process rather than action, it cannot be counted as nominalization.

In consideration for consistency in the analysis, those nouns which served as technical words in each discipline (e.g., digestion in medicine, and competence in applied linguistics) were excluded. As a further stage in the analysis, nominalization instances were tagged through querying for suffixes: nouns ending in the suffixes -ity and -ness were tagged as Type 1 (deriving from adjectives, originally realizing properties); nouns ending in the suffixes -age, -al, -(e)ry, sion /-tion, -ment, -sis, -ure, -ing, and -th were tagged as Type 2 (deriving from verbs, originally realizing processes); and nouns not ending in suffixes were tagged through consulting dictionaries to find the related derivation from adjectives, verbs, prepositions, and conjunctions. Prepositional phrases metaphorically realized as nouns were tagged as type 3. Prepositional phrases often concern information about time and place; in other words, they deal with the circumstances of the events or states described in the text, hence called "circumstantial adjuncts" (Bloor and Bloor, 2004: 53). However, when they change into nouns metaphorically, they become the classifier of nominal groups. Consider the following nominalization instances derived from the corpus:

1. ...fourteenth-century recognition of the connection between... (BR. Med. $\# 014)$

2. Teachers' supervision and assessment of day-to-day performances of students... (BI. AL. \#89)

3. The fourth type, nominalization of conjunction, which is congruently presented by a conjunction, is metaphorically realized by a noun functioning as a participant in the clause. The only pattern manifesting this type of nominalization was as follows:

4. This Handbook is aimed at a diverse range of professionals and for this reason,... (BI. AL. \#051)

5. ...For this reason, color printing has been used to make... (BR. Med. \#037)

In the above examples, the entity reason is transferred from the relator because. In 3, for example, the element reason is the metaphorical realization of the clause because this Handbook is aimed at....

Having identified the frequency, type, and density of nominalizations in the texts as well as the proportion of nominalizations to grammatical metaphors, in the next stage of analysis, we extracted the patterns of nominalizations. The basis for extracting these patterns was Halliday's (2004) suggestion that lexical expansion of nominal groups is attributed to pre/post-modification: a class of things is specified by nouns; and categorization within the class is typically expressed by one or more functional words organized around it. These functional elements - Deictic, Numerative, Epithet, Classifier, and Qualifier - serve to specify things within "different systems of the system network of the nominal 
group" (Halliday, 2004: 312). The classes of the words which typically realize these functions are illustrated in Figure 2:

\begin{tabular}{|c|c|c|c|c|c|c|}
\hline Deictic & Deictic 2 & Numerative & Epithet & Classifier & Thing & Qualifier \\
\hline determiner & adjective & numeral & adjective & $\begin{array}{c}\text { noun/ } \\
\text { adjective }\end{array}$ & Noun & $\begin{array}{c}\text { Prepositional } \\
\text { phrase/ } \\
\text { (in)finite } \\
\text { clause }\end{array}$ \\
\hline
\end{tabular}

Figure 2. Experiential functions and word classes

After about one month interval, the data were re-examined, and discrepancies on the method of analysis were resolved. Considering coding reliability, the data were cross-checked by a linguist to verify the accuracy of categorization of strategies. Then, to calculate the amount of inter-coder and intra-coder reliabilities, Phi correlation was employed twice. The indices obtained were 0.94 and 0.83 , respectively. What follows provides quantitative and qualitative analyses of the materials.

\section{Results}

To address the first and second questions raised in this study, word count was run and the data were normalized afterwards in order to be consistent in our analysis because the number of clauses in the introductions and book reviews was different. The nominalized expressions were, then, counted. A glance at Table 2 reveals that nominalized expressions in applied linguistics outrun the corresponding expressions in medicine in the respective texts:

Table 2. Nominalized Expressions across Disciplines and Genres

\begin{tabular}{lcccccccc}
\hline & \multicolumn{3}{c}{ Applied Linguistics } & \multicolumn{3}{c}{ Medicine } \\
\hline & $\begin{array}{c}\text { Tb. } \\
\text { Intros. }\end{array}$ & $\begin{array}{c}\text { Pb. } \\
\text { Pres. }\end{array}$ & $\begin{array}{c}\text { Tb. } \\
\text { Fors. }\end{array}$ & $\begin{array}{c}\text { Br. } \\
\text { Arts. }\end{array}$ & $\begin{array}{c}\text { Tb. } \\
\text { Inros. }\end{array}$ & $\begin{array}{c}\text { Tb. } \\
\text { Pres. }\end{array}$ & $\begin{array}{c}\text { Tb. } \\
\text { Fors. }\end{array}$ & $\begin{array}{c}\text { Br. } \\
\text { Arts. }\end{array}$ \\
& $\mathrm{F}$ & $\mathrm{F}$ & $\mathrm{F}$ & $\mathrm{F}$ & $\mathrm{F}$ & $\mathrm{F}$ & $\mathrm{F}$ & $\mathrm{F}$ \\
& $(\%)$ & $(\%)$ & $(\%)$ & $(\%)$ & $(\%)$ & $(\%)$ & $(\%)$ & $(\%)$ \\
\hline $\begin{array}{l}\text { Nominalized } \\
\text { expressions }\end{array}$ & 16008 & 10431 & 9367 & 15796 & 12783 & 8971 & 6891 & 11321 \\
& $(8.07)$ & $(8.37)$ & $(9.13)$ & $(9.42)$ & $(6.26)$ & $(8.61)$ & $(6.89)$ & $(8.68)$ \\
\hline Grammatica & 17941 & 12765 & 11651 & 20981 & 14368 & 11509 & 8593 & 18524 \\
l metaphors & & & & & & & & \\
\hline Clauses & 18310 & 11769 & 10976 & 16867 & 18735 & 9873 & 8441 & 12958 \\
\hline Total words & 19831 & 12461 & 10252 & 16753 & 20397 & 10412 & 9998 & 13033 \\
& 4 & 1 & 8 & 3 & 7 & 2 & 3 & 5 \\
\hline
\end{tabular}

Note. Tb. Intros: Textbook Introductions; Tb. Pres.: Textbook Prefaces; Tb. Fors.: Textbook Forewords; Br. Arts.: Book Review Articles. 
Table 2 demonstrates the total number of the nominalized expressions in the analyzed texts. These results reveal the proportion of nominalization instances to grammatical metaphors (i.e. 51602 nominals vis-à-vis 63338 grammatical metaphors in applied linguistics, and 39966 nominals vis-à-vis 52994 grammatical metaphors in medicine). The dominance of nominalization in the categories of grammatical metaphor evinces the valuable role that this strategy plays in formulating scientific discourse. In order to compare the use of nominalization (i.e., adjective to noun (=Type 1), verb to noun (=Type 2), preposition to noun (=Type 3), and conjunction to noun (=Type 4), with their different types of semantic shifts, i.e. quality, process, circumstance, and relator respectively) in detail, the frequency of each nominalized phrase was counted and they were put in appropriate categories (see Table 3):

Table 3. Semantic Shifts in the Use of Nominalized Expressions across Disciplines and Genres

\begin{tabular}{|c|c|c|c|c|c|}
\hline 1. & $\begin{array}{l}\text { Tb. Intros. } \\
\text { (Applied Linguistics) }\end{array}$ & $\begin{array}{l}\text { Tb. Intros. } \\
\text { (Medicine) }\end{array}$ & & & \\
\hline & $\mathrm{F}(\%)$ & $\mathrm{F}(\%)$ & $\mathrm{df}$ & $\mathrm{X}^{2}$ & $\mathrm{P}$ value \\
\hline Type 1 & $1021(6.37)$ & $772(6.04)$ & 1 & 277.64 & 0.000 \\
\hline Type 2 & $14460(90.32)$ & $11453(89.59)$ & 1 & 581.89 & 0.000 \\
\hline Type 3 & $482(3.01)$ & $507(3.96)$ & 1 & 105.58 & 0.000 \\
\hline Type 4 & $45(0.28)$ & $51(0.39)$ & 1 & 7.92 & 0.005 \\
\hline \multirow[t]{2}{*}{2.} & $\begin{array}{l}\text { Tb. Pres. } \\
\text { (Applied Linguistics) }\end{array}$ & $\begin{array}{l}\text { Tb. Pres. } \\
\text { (Medicine) }\end{array}$ & & & \\
\hline & $\mathrm{F}(\%)$ & $\mathrm{F}(\%)$ & $\mathrm{df}$ & $\mathrm{X}^{2}$ & $P$ value \\
\hline Type 1 & $752(7.20)$ & $571(6.36)$ & 1 & 329.93 & 0.000 \\
\hline Type 2 & $9249(88.66)$ & $8128(90.60)$ & 1 & 308.35 & 0.000 \\
\hline Type 3 & $411(3.94)$ & $250(2.79)$ & 1 & 247.49 & 0.000 \\
\hline Type 4 & $19(0.18)$ & $22(0.25)$ & 1 & 3.12 & 0.077 \\
\hline \multirow[t]{2}{*}{3.} & $\begin{array}{l}\text { Tb. Fors. } \\
\text { (Applied Linguistics) }\end{array}$ & $\begin{array}{l}\text { Tb. Fors. } \\
\text { (Medicine) }\end{array}$ & & & \\
\hline & $\mathrm{F}(\%)$ & $\mathrm{F}(\%)$ & $\mathrm{df}$ & $\mathrm{X}^{2}$ & $\mathrm{P}$ value \\
\hline Type 1 & $725(7.73)$ & $406(5.89)$ & 1 & 481.84 & 0.000 \\
\hline Type 2 & $8261(88.19)$ & $6161(89.40)$ & 1 & 372.15 & 0.000 \\
\hline Type 3 & $358(3.82)$ & $304(4.41)$ & 1 & 128.20 & 0.000 \\
\hline Type 4 & $23(0.25)$ & $21(0.30)$ & 1 & 7.10 & 0.008 \\
\hline \multirow[t]{2}{*}{4.} & $\begin{array}{l}\text { Br. Arts. } \\
\text { (Applied Linguistics) }\end{array}$ & $\begin{array}{l}\text { Br. Arts. } \\
\text { (Medicine) }\end{array}$ & & & \\
\hline & $\mathrm{F}(\%)$ & $\mathrm{F}(\%)$ & $\mathrm{df}$ & $\mathrm{X}^{2}$ & $P$ value \\
\hline Type 1 & $835(5.29)$ & $756(6.68)$ & 1 & 262.53 & 0.000 \\
\hline Type 2 & $14551(92.12)$ & $10099(89.21)$ & 1 & 857.77 & 0.000 \\
\hline Type 3 & $356(2.25)$ & $408(3.60)$ & 1 & 60.48 & 0.000 \\
\hline Type 4 & $52(0.33)$ & $57(0.50)$ & 1 & 10.13 & 0.001 \\
\hline \multirow[t]{2}{*}{5.} & $\begin{array}{l}\text { All Textbook } \\
\text { Introduction Genres } \\
\text { (Applied Linguistics) }\end{array}$ & $\begin{array}{l}\text { Br. Arts. } \\
\text { (Applied Linguistics) }\end{array}$ & & & \\
\hline & $\mathrm{F}(\%)$ & $\mathrm{F}(\%)$ & $\mathrm{df}$ & $\mathrm{X}^{2}$ & $P$ value \\
\hline Type 1 & $2498(5.91)$ & $835(5.29)$ & 1 & 1299.68 & 0.000 \\
\hline Type 2 & $31970(75.69)$ & $14551(92.12)$ & 1 & 285.46 & 0.000 \\
\hline
\end{tabular}




\begin{tabular}{|c|c|c|c|c|c|}
\hline Type 3 & $1251(2.96)$ & $356(2.25)$ & 1 & 1412.98 & 0.000 \\
\hline Type 4 & $87(0.20)$ & $52(0.33)$ & 1 & 53.54 & 0.000 \\
\hline \multirow[t]{2}{*}{6.} & $\begin{array}{l}\text { All Textbook } \\
\text { Introduction } \\
\text { Genres (Medicine) }\end{array}$ & $\begin{array}{l}\text { Br. Arts. } \\
\text { (Medicine) }\end{array}$ & & & \\
\hline & $\mathrm{F}(\%)$ & $\mathrm{F}(\%)$ & $\mathrm{df}$ & $\mathrm{X}^{2}$ & $P$ value \\
\hline Type 1 & $1749(6.10)$ & $756(6.68)$ & 1 & 143.31 & 0.000 \\
\hline Type 2 & $25842(90.21)$ & $10099(89.21)$ & 1 & 245.10 & 0.000 \\
\hline Type 3 & 1061(3.70) & $408(3.60)$ & 1 & 1361.76 & 0.000 \\
\hline Type 4 & $94(0.32)$ & $57(0.50)$ & 1 & 56.82 & 0.000 \\
\hline
\end{tabular}

Note. Tb. Intros: Textbook Introductions; Tb. Pres.: Textbook Prefaces; Tb.Fors.: Textbook Forewords; Br. Arts.: Book Review Articles.

The results of chi-square analyses showed significant differences between the genres in focus in the two disciplines under study. Table 3 reveals the most and the least nominalized expressions used in the corpus. That is, verb to noun was extremely common and unmarked in the two disciplines. Adjective to noun ranked second in order of frequency in these academic texts. As shown by chi-square analysis, preposition to noun was used more frequently in applied linguistics than in medicine. Finally, though not significantly different, conjunction to noun was very scant in the focused texts for analysis and proved to be similarly employed in the two disciplines. The results marked verb to noun to be characteristic of the discourse of the two disciplines.

Table 4. Density of Nominalized Expressions in Textbook Introductions and Book Reviews

\begin{tabular}{llllll}
\hline 1. & $\begin{array}{l}\text { Tb. Intros. } \\
\text { (Applied } \\
\text { Linguistics) }\end{array}$ & $\begin{array}{l}\text { Tb. Intros. } \\
\text { (Medicine) }\end{array}$ & & & \\
\hline & $\mathrm{F}(\%)$ & $\mathrm{F}(\%)$ & $\mathrm{Df}$ & $\mathrm{X}^{2}$ & P value \\
\hline $\begin{array}{l}\text { Nominalized } \\
\text { expressions }\end{array}$ & $16380(87.42)$ & $12783(68.23)$ & 1 & 684.50 & 0.000 \\
\hline Number of clauses & 18735 & 18735 & & & \\
\hline 2. & Tb. Pres. & Tb. Pres. & & & \\
\hline & $\mathrm{F}(\%)$ & $\mathrm{F}(\%)$ & $\mathrm{Df}$ & $\mathrm{X}^{2}$ & P value \\
\hline $\begin{array}{l}\text { Nominalized } \\
\text { expressions }\end{array}$ & $10431(88.63)$ & $9710(82.50)$ & 1 & 409.81 & 0.000 \\
\hline Number of clauses & 11769 & 11769 & & & \\
\hline 3. & Tb. Fors. & Tb. Fors. & & & \\
\hline & $\mathrm{F}(\%)$ & $\mathrm{F}(\%)$ & $\mathrm{Df}$ & $\mathrm{X}^{2}$ & P value \\
\hline $\begin{array}{l}\text { Nominalized } \\
\text { expressions }\end{array}$ & $9367(85.34)$ & $8961(81.63)$ & 1 & 259.98 & 0.000 \\
\hline Number of clauses & 10976 & 10976 & & & \\
\hline 4. & Br. Arts. & Br. Arts. & & & \\
\hline & $\mathrm{F}(\%)$ & $\mathrm{F}(\%)$ & $\mathrm{Df}$ & $\mathrm{X}^{2}$ & P value \\
\hline
\end{tabular}




\begin{tabular}{llllll}
\hline $\begin{array}{l}\text { Nominalized } \\
\text { expressions }\end{array}$ & $15796(93.65)$ & $14736(87.36)$ & 1 & 465.84 & 0.000 \\
\hline Number of clauses & 16867 & 16867 & & & \\
\hline
\end{tabular}

Note. Tb. Intros: Textbook Introductions; Tb. Pres.: Textbook Prefaces; Tb. Fors.: Textbook Forewords; Br. Arts.: Book Review Articles.

As for the third research question, Table 4 demonstrates the density of the nominalized expressions in the clauses in the four datasets. The chi-square revealed a statistically significant difference with regard to the density of the nominalized expressions in the focused genres. That is, the amount of the chisquare was higher than the critical value (3.84) at the level of $p<0.05$. The density of the nominalized expressions in applied linguistics exceeded the corresponding expressions in medicine, showing that the writers in applied linguistics tend to condense and package a larger amount of information into single lexical items than in medicine.

Table 5. Nominalized Expressions and Grammatical Metaphors in Introductions and Book Reviews

\begin{tabular}{|c|c|c|c|c|c|}
\hline 1. & $\begin{array}{c}\text { Tb. Intros. } \\
\text { (Applied } \\
\text { Linguistics) }\end{array}$ & $\begin{array}{l}\text { Tb. Intros. } \\
\text { (Medicine) }\end{array}$ & & & \\
\hline & $\mathrm{F}(\%)$ & $\mathrm{F}(\%)$ & $\mathrm{df}$ & $X^{2}$ & $P$ value \\
\hline $\begin{array}{c}\text { Nominalized } \\
\text { expressions }\end{array}$ & $16008(89.22)$ & $15962(88.96)$ & 1 & 402.50 & 0.000 \\
\hline $\begin{array}{c}\text { Grammatical } \\
\text { metaphors }\end{array}$ & 17941 & 17941 & & & \\
\hline \multirow[t]{2}{*}{2.} & $\begin{array}{l}\text { Tb. Pres. } \\
\text { (Applied } \\
\text { Linguistics) }\end{array}$ & $\begin{array}{l}\text { Tb. Pres. } \\
\text { (Medicine) }\end{array}$ & & & \\
\hline & $\mathrm{F}(\%)$ & $\mathrm{F}(\%)$ & $\mathrm{df}$ & $\mathrm{X}^{2}$ & $\mathrm{P}$ value \\
\hline $\begin{array}{c}\text { Nominalized } \\
\text { expressions }\end{array}$ & $10431(81.71)$ & $9950(77.94)$ & 1 & 292.02 & 0.000 \\
\hline $\begin{array}{c}\text { Grammatical } \\
\text { metaphors }\end{array}$ & 12765 & 12765 & & & \\
\hline \multirow[t]{2}{*}{3.} & $\begin{array}{l}\text { Tb. Fors. } \\
\text { (Applied } \\
\text { Linguistics) }\end{array}$ & $\begin{array}{l}\text { Tb. Fors. } \\
\text { (Medicine) }\end{array}$ & & & \\
\hline & $\mathrm{F}(\%)$ & $\mathrm{F}(\%)$ & $\mathrm{df}$ & $X^{2}$ & $\mathrm{P}$ value \\
\hline $\begin{array}{c}\text { Nominalized } \\
\text { expressions }\end{array}$ & $9367(80.39)$ & 9343(80.19) & 1 & 236.13 & 0.000 \\
\hline $\begin{array}{c}\text { Grammatical } \\
\text { metaphors }\end{array}$ & 11651 & 11651 & & & \\
\hline \multirow[t]{2}{*}{4.} & $\begin{array}{l}\text { Br. Arts. } \\
\text { (Applied } \\
\text { Linguistics) }\end{array}$ & $\begin{array}{l}\text { Br. Arts. } \\
\text { (Medicine) }\end{array}$ & & & \\
\hline & $\mathrm{F}(\%)$ & $\mathrm{F}(\%)$ & df & $\mathrm{X}^{2}$ & $\mathrm{P}$ value \\
\hline $\begin{array}{l}\text { Nominalized } \\
\text { expressions }\end{array}$ & $15796(75.28)$ & $12823(61.11)$ & 1 & 615.06 & 0.000 \\
\hline
\end{tabular}


Grammatical 20981 20981

metaphors

Note. Tb. Intros: Textbook Introductions; Tb. Pres.: Textbook Prefaces; Tb. Fors.: Textbook Forewords; Br. Arts.: Book Review Articles.

Table 5 reveals the final stage of the quantitative analyses which demonstrates the proportion of the normalized nominalized expressions to the total number of grammatical metaphors in each of the four genres under scrutiny in the two disciplines. The chi-square statistics revealed a statistically significant difference (at $\mathrm{p}<0.05$ ). The nominalized expressions in applied linguistics were more prevalent than in medicine. This shows that the presentation of information in applied linguistics is facilitated more by the use of nominalized expressions through the expansion and elaboration of nominal elements than in medicine.

With regard to the fourth research question, in all focused genres, Type 2 (i.e., conversion of verb to noun (process)) was reported to be more prevalent than other types of nominal expressions. There were different patterns in which Type 2 occurred. Table 6 summarizes the most frequent patterns with their related examples.

Table 6. Summary of Patterns and Related Examples

\begin{tabular}{|c|c|c|c|}
\hline \multirow{2}{*}{$\begin{array}{c}\text { Pattern } \\
\text { No. }\end{array}$} & \multirow[b]{2}{*}{ Patterns and related examples } & \multicolumn{2}{|c|}{ Frequency } \\
\hline & & AL. & Med. \\
\hline \multirow[t]{2}{*}{$\# 1$} & Nominal + Qualifier & 9904 & 9277 \\
\hline & $\begin{array}{l}\text { With careful cross-referencing and provision of explanations } \\
\text { and examples, we have ... (BI. AL. \#004) }\end{array}$ & $19.19 \%$ & $23.21 \%$ \\
\hline
\end{tabular}

\begin{tabular}{|c|c|c|c|}
\hline$\# 2$ & $\begin{array}{c}\text { Preposition }+ \text { Nominal } \\
\text { In comparison, this manual is a collective effort to provide } \\
\text { simple, practical solutions to... (BF. Med. \#010) }\end{array}$ & $\begin{array}{c}1423 \\
2.76 \%\end{array}$ & $\begin{array}{c}1245 \\
3.12 \%\end{array}$ \\
\hline$\# \mathbf{3}$ & $\begin{array}{l}\qquad a / \text { an/the } /-+ \text { nominal } \\
\ldots, \text { and the reconstructive flap illustrations are well-done and } \\
\text { reproducible for broad study and recall. } \text { (BR. Med. \#081) }\end{array}$ & $\begin{array}{c}2153 \\
4.17 \%\end{array}$ & $\begin{array}{c}1287 \\
3.22 \%\end{array}$ \\
\hline$\# 4$ & $\begin{array}{l}\text { there/is/are/was/were }+ \text { nominal } \\
\text { There are illustrations } \text { added in this edition wherever } \\
\text { important points could be made more clear,...(BP. Med. \#016) }\end{array}$ & $\begin{array}{c}2243 \\
4 \%\end{array}$ & $\begin{array}{c}1066 \\
2.67 \%\end{array}$ \\
\hline \# 5 & $\begin{array}{l}\text { Nominal }+ \text { Prepositional Phrase } \\
\text {...but treatment of other contact phenomena is less } \\
\frac{\text { sure...(BR. AL. \#085) }}{}\end{array}$ & $\begin{array}{l}9147 \\
18 \%\end{array}$ & $\begin{array}{c}7454 \\
18.65 \%\end{array}$ \\
\hline \#6 & $\begin{array}{c}\text { Preposition }+ \text { Nominal }+ \text { Prepositional Phrase } \\
\text { We are pleased that Springer has taken this title under its } \\
\text { direction and has helped to improve its quality in preparation } \\
\text { for international release (BP. Med. } \# \text { (089). }\end{array}$ & $\begin{array}{c}205 \\
0.39 \%\end{array}$ & $\begin{array}{c}189 \\
0.47 \%\end{array}$ \\
\hline
\end{tabular}




\begin{tabular}{|c|c|c|c|}
\hline$\# 7$ & $\begin{array}{l}\text { Classifier }+ \text { Nominal } \\
\text {...provides examples specific to healthcare on how hospitals } \\
\text { have greened their operations and facilities, ranging from } \\
\text { healthy food procurement, to hospital waste, to measuring } \\
\text { and...(BR. Med. \#014) }\end{array}$ & $\begin{array}{l}5043 \\
10 \%\end{array}$ & $\begin{array}{c}6359 \\
15.91 \%\end{array}$ \\
\hline \# 8 & $\begin{array}{c}\text { Nominal as classifier }+ \text { Nominal/ Noun } \\
\text { Chapter } 1 \text { gives an overview of the green healthcare } \\
\text { movement }, \ldots(\mathrm{BR} . \text { Med. \#014) }\end{array}$ & $\begin{array}{c}5045 \\
9.77 \%\end{array}$ & $\begin{array}{c}2034 \\
5.09 \%\end{array}$ \\
\hline$\# 9$ & $\begin{array}{l}\text { Classifier }+ \text { Classifier }+ \text { Nominal } \\
\text { In recognition of the growing excitement and potential of ES } \\
\text { cells as models for both the advancement of future clinical } \\
\text { applications and, ...(BP. Med. \#003) }\end{array}$ & $\begin{array}{l}937 \\
2 \%\end{array}$ & $\begin{array}{c}1536 \\
3.84 \%\end{array}$ \\
\hline$\# 10$ & $\begin{array}{c}\text { Numerative }+ \text { Nominal } \\
\text { One concern is to explore the nature of temporal frames of } \\
\text { reference...(BP. AL. \#098) }\end{array}$ & $\begin{array}{c}1821 \\
4 \%\end{array}$ & $\begin{array}{c}1342 \\
3.36 \%\end{array}$ \\
\hline \# 11 & $\begin{array}{l}\text { Nominal }+ \text { Participle } \\
\text { The information contained herein... (BF. Med. \#011) }\end{array}$ & $\begin{array}{c}1952 \\
4 \%\end{array}$ & $\begin{array}{c}2374 \\
5.94 \%\end{array}$ \\
\hline$\# 12$ & $\begin{array}{l}\text { Nominal }+ \text { Relative clause } \\
\text {... A more reasonable expectation that interested readers will } \\
\text { simply select the chapters that ... (BI. AL. \#001) }\end{array}$ & $\begin{array}{l}3575 \\
7 \%\end{array}$ & $\begin{array}{c}2242 \\
5.61 \%\end{array}$ \\
\hline$\# 13$ & $\begin{array}{c}\text { Nominal }+ \text { Gerund } \\
\text { However, in view of rapid } \text { changes occurring in medical } \\
\text { science,... (BF. Med. \#011) }\end{array}$ & $\begin{array}{l}971 \\
2 \%\end{array}$ & $\begin{array}{c}552 \\
1.38 \%\end{array}$ \\
\hline \# 14 & $\begin{array}{l}\text { Nominal }+ \text { Adjunct } \\
\text { This is addressed in greater } \frac{\text { depth in chapter } 11 \ldots}{(B I . ~ M e d . ~} \\
\# 085)\end{array}$ & $\begin{array}{l}729 \\
1 \%\end{array}$ & $\begin{array}{c}184 \\
0.46 \%\end{array}$ \\
\hline$\# 15$ & $\begin{array}{c}\text { Nominal }+ \text { Infinitive } \\
\text { We are most grateful to him for his permission to do this. (BP. } \\
\text { Med. \#036) }\end{array}$ & $\begin{array}{l}973 \\
2 \%\end{array}$ & $\begin{array}{c}367 \\
0.92 \%\end{array}$ \\
\hline \# 16 & $\begin{array}{c}\text { Nominal }+ \text { Adjective/Adverb as postmodifier } \\
\text {...about the accuracy of the scientific information } \\
\text { communicated by many..... (BR. Med.\#009) } \\
\text {... to base their practice individually... (BR. Med. \#008) }\end{array}$ & $\begin{array}{l}842 \\
2 \%\end{array}$ & $\begin{array}{c}362 \\
0.91 \%\end{array}$ \\
\hline \# 17 & $\begin{array}{l}\text { Adverb as classifier + Nominal } \\
\text { No attempt was made to do experimental tests under carefully } \\
\text { controlled plans... (BF. AL. \#001) }\end{array}$ & $\begin{array}{l}631 \\
1 \%\end{array}$ & $\begin{array}{c}345 \\
0.86 \%\end{array}$ \\
\hline$\# 18$ & $\begin{array}{l}\text { This/that/these/those+Nominalization } \\
\text { This reference is a not-so-quick one... (BR. Med. \#070) }\end{array}$ & $\begin{array}{c}4011 \\
7.77 \%\end{array}$ & $\begin{array}{c}1751 \\
4.38 \%\end{array}$ \\
\hline$\Sigma$ & & 51602 & 39966 \\
\hline
\end{tabular}

Note. Med: Medicine; AL.: Applied linguistics.

The most dominant pattern was nominalization + qualifier (\#1). In the examples below, the congruent forms of Example 5 are the part of the section that remains addresses, and the fact that hypertext and modern media can influence comprehensibility..., and the congruent forms of Example 6 are the students' efforts have come out.., and They considerably experienced teaching biochemistry... The words remainder, influence, outcome, and experience 
function as things in these nominal expressions, and the words section, hypertext, and modern media, efforts, and teaching which serve as qualifier in metaphoric forms, are, in fact, the head of material processes in their congruent realizations. Therefore, they belong to the ideational grammatical metaphor because their grammatical functions are transferred from Head to qualifier:

5. The remainder of the section addresses issues like the influence of hypertext and modern media on comprehensibilty and translating professional documents (BR. AL. \#004)

6. The textbook of Medical Biochemistry for the medical students is the outcome of the joint efforts of a medical and a nonmedical biochemist, who possess considerable experience in teaching biochemistry to undergraduate and postgraduate medical students of Indian universities. (BP. Med. \#33)

In some cases, from the grammatical point of view, nominalizing a process allows the addition of both modifiers and qualifiers packing the flow of information into fewer words. Note the following examples:

7. The last decade has witnessed an explosive growth of molecular data ... (BP. Med. \#018)

8. ...that should be taken into account to give the reader a scientific understanding of the writing process relative to planning ... (BR. AL. \#009)

(The typical form of Example 7 is molecular data grows explosively. Example 8 is represented congruently as writing process is understood scientifically.)

The rest of the patterns excluded from the analyses indicated that the dense clauses are usually formed by nouns with multiple premodifiers and postmodifiers in both disciplines. This, in effect, creates a text that is tightly packed with information in the form of nominal phrases rather than clauses to add information (Gray and Biber, 2010).

\section{Discussion}

The main findings of this study with respect to introductions and book reviews in medicine and applied linguistics are discussed below.

As revealed by the results of the four research questions, the similarities and differences in nominalization deployment in the four genres is likely to illustrate different tendencies for packaging the information in academic texts which involve fluctuation over the use of this strategy in the different types of texts. Although all texts were replete with instances of nominalizations, the introduction sections of textbooks had comparatively the most frequent distributions of nominals, whereas the book review articles had the least number of nominals. Prefaces and forewords were fairly similar in their frequencies of nominals. These results confirm that grammatical metaphor is a powerful language resource that 
"simultaneously builds cohesion, foregrounds meanings in static nominal groups, and backgrounds personal and subjective voice".

Furthermore, information density is intimately tied to disciplinary characteristics. In this respect, grammatical metaphor is a resource that language uses to condense information by expressing concepts in an incongruent form which is very valued in scientific registers as a way of expressing "objectification" and "abstraction" (Halliday and Martin, 2005: 33). However, unlike other studies (Halliday, 1994; Halliday and Martin, 2005; Xue-feng, 2010), the writers in both disciplines put ideas into abstract forms variably and thus, at the level of lexicogrammar, the disciplinary distinction is manifested in the degree of the nominal phrases used.

Besides the density of nominal phrases that distinguishes the two disciplines, there were a few patterns that made the applied linguistics texts distinct from the texts in medicine. For instance, adjective-derived nominalization in applied linguistics mostly occurs in the clause initial position. In the following example, the writer explains why writers are required to act uniformly in emphasizing consistency in the next clause:

9. Consistency is a necessary characteristic of polished, highly readable prose. (BI. AL. \#076)

Another recurring pattern characterizing applied linguistics is the nominalization of adjective and qualifier or nominalization of adjective with another adjective as illustrated below:

10. ... the importance of accessibility of curriculum to the language teacher as a tool for increasing ... (BR. AL. \#019)

The pattern exclusive to medicine, which establishes the cause and effect relationship between the nominal groups, is of simple construction, with one nominal group clause initially, the importance of genes, one nominal group clause finally, their ability, and one verbal group, lies in, pushed in between indicating the logical relation between the two phenomena. Note the following example which is congruently taken to be because genes are able to control the formation of cell, they are important:

\section{The importance of genes lies in their ability to determine key personality} traits, as well as... (BI. Med. \#31))

A noticeable difference in the use of prepositional nominalization in applied linguistics and medicine is revealed in the next two examples. Whereas, in medicine introductory genres, the nominalization of preposition occurs with nominalization of process and qualifier, in applied linguistics, nominalization of preposition often occurs before nominalization of process as shown below: 
12. As language learning is a cumulative effort, it must be consolidated outside ... (BR. AL. \#007))

13. The juristic basis of the classification of disease is concerned with the legal circumstances in which death occurs. (BI. Med. \#026)

Therefore, even if there arguably are core features and characteristics in academic discourse, it is important to acknowledge the fact that many variations exist when it comes to how certain disciplines struggle with the challenges of conveying information and achieving academic writing. Various disciplines in the natural sciences, technology, social sciences, and humanities have their specific, conventionalized ways of describing ideas, knowledge, methods, results and interpretations (e.g., Basturkmen, 2011; Hawes and Thomas, 2012; McGrath and Kuteeva, 2013; Parodi, 2010). This discipline specificity, which stresses the distinctive ways of meaning making and constructing discourse (Hyland, 2009), attempted to highlight the necessity to go beyond the generalized view of academic writing and to pin down specific characteristics of the scientific discourse in each of these disciplines.

One other major finding drawn from our analysis was the greater density of nominalization in applied linguistics than medicine. This being said, in formal written language, there are fewer clauses, as the ideational information of two or more clauses may be realized as one. Thus, the possibility of two or more cases of grammatical metaphor being combined in the same nominal group would mean that two or more clauses are being expressed as a single participant. This feature prevails in applied linguistics because the writers tend to put the focus on objects, states, and process all encoded by nouns rather than human agents and their actions which are, in turn, encoded by verbs (Jalilifar, Alipour, and Parsa, 2014). Thus, it seems reasonable to assume that information density is closely related to disciplinary characteristics. Previous studies (e.g., Galve, 1998; Halliday, 1994) have also measured lexical density by dividing the number of lexical items to the number of ranking clauses. Galve (1998) argued that when a language is more planned and more formal, lexical density is higher (over 0.40 per clause). When processes are repacked as participants, academic texts become more abstract and complex, and much of the complexity is due to the nominal group structure which allows an extended explanation to be condensed into a complex phrase, as depicted in the following example:

14. The earliest activities in the documentation and description of language have been attributed to... (BI. AL. \#093)

Therefore, writers and speakers make choices from the various options that language makes available, according to the social and cultural context in which meaning is exchanged. As an interlocking set of grammatical systems, language enables its users to make different kinds of meaning for different purposes and contexts. Schleppegrell (2001) argues that register differences manifest 
themselves both in choice of words or phrases and also in the way that clauses are constructed and linked. Therefore, the higher proportion of lexical density in applied linguistics in comparison to medicine reveals that the language that constructs knowledge is subject to disciplinary specificities. The choice of different lexical and grammatical options is related to the functional purposes that are foregrounded by the writers of different disciplines. Lexical density is one way of qualifying the differences in lexical choices.

\section{Conclusion}

The research undertaken in this study can contribute to better understanding of nominalization in textbook introductions and book reviews. In this regard, it can help those who attempt to know the role and function of nominalization in scientific writing and as a writing style of academic discourse. Nominalization is closely linked to the principles of economy (Zhou, 2012). Being a form of condensation of information, nominalization is a very efficient means of bundling information and consequently frequently used in formal writing. When compared with verbs, nominalizations can be more ambiguous due to valency reduction but they also provide valuable opportunities to organize discourse and express abstract relations among processes in a more efficient way. Hence, the realized differences in deployment of nominal groups in textbook introductions of harder and softer sciences can be pedagogically inspiring. Indeed, developing an awareness of the functions of nominalization - for example, enabling writers to pack more information in fewer clauses and increase information load of the text, expressing particularity by using classifiers in nominal phrases, elaborating and clarifying concepts by using relative clauses as postmodifiers for nominalizations - helps novice writers understand how this writing feature might help shape their writing in their specific discipline in a more compact and dense manner.

Furthermore, in the domain of pedagogy, teachers can make students aware of the complexity of language and how language works to compress various meanings in a sentence. Instruction of such rhetorical strategies can create an awareness of how by use of nominalization a single clause compacts several complex abstract ideas and makes language complex for the students. Thus, they need to learn a basic knowledge of grammatical metaphor and the different ways it is expressed in academic discourse.

The present study investigated the role of nominalization in applied linguistics and medicine textbook introduction genres and book reviews based on the model of grammatical metaphor proposed by Halliday and Mathiessen (1999). As the study was based on a limited data set, the results cannot be seen as conclusive. Further studies working on other disciplines can create opportunities for researchers to reflect on disciplinary characteristics. Nominalization can also be examined in other genres to determine the way nominal items are realized in 
different contexts. Furthermore, our knowledge of nominalization in languages other than English is very sparse. To offset the balance, the nominal expression types used in English scientific discourse can be compared with those used in other languages to see how cross-cultural differences might play a role in using this feature of language which leads to concomitant decisions on the text texture. Given that the study design was text-based, this investigation can be extended by enquiring into academic writers' intentions and awareness about using nominal expressions in their writing. Interviews might be designed so as to gain insights into why the academic writers make use of particular patterns of nominalizations in developing their texts.

\section{References}

Abdollahzadeh, Esmaeel and Hossein Salarvand. 2013. Book prefaces in basic, applied, and social sciences: A genre-based study. Journal of World Applied Sciences, 28(11), 1618-1626.

Alcaraz-Ariza, María Ángeles. 2010. Complimenting others: The case of English-written medical book reviews. Fachsprache, 31(1-2), 50-65.

Banks, David. 2003. The evolution of grammatical metaphor in scientific writing. In: Anne-Marie Simon-Vandenbergen, Miriam Taverniers and Louise J. Ravelli (eds.), Grammatical Metaphor: Views from Systemic Functional Linguistics, 127-147. Amsterdam: John Benjamins.

Banks, David. 2005.On the historical origins of nominalized process in scientific texts. English for Specific Purposes, 24(3), 347-357.

Baratta, Alexander M. 2010. Nominalization development across an undergraduate academic degree program. Journal of Pragmatics, 42(4), 1017-1036.

Bhatia, Vijay K. 1993. Analyzing Genre: Language Use in Professional Settings. London: Longman.

Bhatia, Vijay K. 1997. Genre mixing in academic introductions. Journal of English for Specific Purposes, 16(3), 181-195.

Bhatia, Vijay K. 2002. Applied genre analysis: A multi-perspective model. Ibérica, 4(1), 3-19.

Bhatia, Vijay K. 2004. Worlds of Written Discourse: A Genre-based View. London: Continuum.

Bloor, Tom and Meriel Bloor. 2004. The Functional Analysis of English: A Hallidayan Approach. London: Arnold.

Bunton, David. 2002. Generic moves in PhD thesis introductions. In: John Flowerdew (ed.), Academic Discourse, 57-75. London: Longman.

Coffin, Caroline, Curry, Mary J., Goodman, Sharon, Hewings, Ann, Lillis, Theresa M. and Joan Swann. 2003. Teaching Academic Writing: A Toolkit for Higher Education. London: Routledge.

Diani, Giuliana. 2007. Reporting and evaluation in English book review articles: a cross disciplinary study. In: Ken Hyland and Giuliana Diani (eds.), Academic Evaluation: Review Genres in University Settings. 87-105. New York: Palgrave Macmillan.

Dudley-Evans, Tony. 1986. Genre analysis: An investigation of the introduction and discussion sections of MSc dissertations. In Malcolm Coulthard (ed.), Talking about Text: Studies Presented to David Brazil on his Retirement, 128-145. Birmingham: ELR.

Eggins, Suzanne. 2004. An Introduction to Systemic Functional Linguistics. London: Continuum.

Farahani, Ali Akbar and Yaser Hadidi. 2008. Semogenesis under scrutiny: Grammatical metaphor in science and modern prose fiction. Iranian Journal of Applied Linguistics, 11(2), 51-82.

Galve, Guillén I. 1998. The textual interplay of grammatical metaphor on the nominalization occurring in written medical English. Journal of Pragmatics, 30(3), 363-385.

Gea Valor, Maria-Lluisa and María Mar del Saz Rubio. 2000-2001. The coding of linguistic politeness in the academia book review. Pragmalingüistica, 8-9, 165-178. 
Gesuato, Sara. 2004. Read Me First: Promotional strategies in back-cover blurbs. Paper presented at the 2nd Inter-Varietal Applied Corpus Studies Conference, Belfast, 25th-26th June. [Online] Available from: http://www.units.it/ didactas/pub/unipd/presIVACS 2004.doc. [Accessed: 14th March 2015].

Giannoni, Davide Simone. 2009. Negotiating research values across review genres: A case study in applied linguistics. In: Ken Hyland and Giuliana Diani (eds.), Academic Evaluation: Review Genres in University Settings, 17-33. Houndmills: Palgrave Macmillan.

Glanzel, Wolfgang and András Schubert, 2003. A new classification scheme of science fields and subfields designed for scientometric evaluation purposes. Scientometrics, 56 (3), 357-367.

Gray, Bethany and Douglas Biber. 2010. Challenging stereotypes about academic writing: Complexity, elaboration, explicitness. English for Academic Purposes, 9(1), 2-20.

Groom, Nicholas. 2009. Phraseology and epistemology in academic book reviews: A corpus-driven analysis of two humanities disciplines. In: Ken Hyland and Giuliana Diani (eds.), Academic Evaluation: Review Genres in University Settings, 122-39. Houndmills: Palgrave Macmillan.

Halliday, Michael A. K. 1994. An Introduction to Functional Grammar (2nd ed.). London: Edward Arnold.

Halliday, Michael A. K. 2004. An Introduction to Functional Grammar (3rd ed., revised by Christian M. I. M. Matthiessen). London: Arnold.

Halliday, Michael A. K. and James R. Martin. 2005. Writing Science: Literacy and Discursive Power. Pittsburgh: University of Pittsburgh Press.

Halliday, Michael A. K. and Christian M. I. M. Matthiessen. 1999. Construing Experience through Meaning: A Language-based Approach to Cognition. London: Cassell.

Halliday, Michael A. K. and Christian M. I. M. Matthiessen. 2004. An Introduction to Functional Grammar. London: Arnold.

Heyvaert, Liesbet. 2003. Nominalization as grammatical metaphor: On the need for a radically systemic and metafunctional approach. In: Anne-Marie Simon-Vandenbergen, Miriam Taverniers and Louise J. Ravelli (eds.), Grammatical Metaphor: Views from Systemic Functional Linguistics, 65-99. Amsterdam: John Benjamins.

Ho, Victor. 2010. Grammatical metaphor in request e-mail discourse. Applied Language Studies, 14(1), 1- 24.

Holmes, Richard. 1997. Genre analysis and the social sciences: An investigation of the structure of research article discussion sections in three disciplines. English for Specific Purposes, 16, $321-$ 337.

Holtz, Mônica. 2009. Nominalization in scientific discourse: A corpus-based study of abstracts and research articles. In: Michaela Mahlberg, Victorina Gonzalez-Diaz and Catherine Smith (eds.), Proceedings of the $5^{\text {th }}$ Corpus Linguistics Conference Liverpool, UK. September $25^{\text {th }}$. [Online] Available from: http://ucrel.lancs.ac.uk/publications/cl2009/. [Accessed: 4th May 2015].

Hopkins, Andy and Tony Dudley-Evans. 1988. A genre-based investigation of the discussion sections in articles and dissertations. English for Specific Purposes, 7, 113-122.

Hyland, Ken. 2004. Disciplinary Discourses: Social Interactions in Academic Writing. Ann Arbor: The University of Michigan Press.

Hyland, Ken. 2006. English for Academic Purposes: An Advanced Resource Book. London: Routledge.

Hyland, Ken. 2009. Academic Discourse: English in a Global Context. London: Continuum.

Hyland, Ken and Giuliana Diani. 2009. Academic Evaluation: Review Genres in University Settings. London: Palgrave-MacMillan.

Hyon, Sunny. 1996. Genre in three traditions: Implications for ESL. TESOL Quarterly, 30, 693722.

Jalilifar, Alireza, Alipour, Mohammad and Sara Parsa. 2014. Comparative study of nominalization in applied linguistics and biology books. RALs, 5(1), 24-43. 
Jalilifar, Alireza, and Zeinab Golkar Musavi. 2016. Genre analysis and genre-mixing across various realizations of academic book introductions in applied linguistics. Journal of Teaching Language Skills, 35(1), 111-138.

Kuhi, Davud. 2008. An analysis of move structure of textbook prefaces. Asian ESP Journal, 7, 6378.

Kuteeva, Maria. 2013. English in academic and professional contexts. Nordic Journal of English Studies, 13(1), 1-6.

Lindholm-Romantschuk, Ylva. 1998. Scholarly Book Reviewing in the Social Sciences and Humanities: The Flow of Ideas within and among Disciplines. Westport: Greenwood Publishing Group.

Lock, Graham. 1996. Functional English Grammar: An Introduction for Second Language Teachers. Cambridge: Cambridge University Press.

Lorés Sanz, Rosa. 2012. (Non-)critical voices in the reviewing of history discourse: A cross-cultural study of evaluation. In: Ken Hyland and Giuliana Diani (eds.), Academic Evaluation: Review Genres in University Settings, 143-160. Houndmills: Palgrave Macmillan.

Marefat, Hamideh and Shirin Mohammadzadeh. 2013. Genre analysis of literature research article abstracts: A cross-linguistic, cross-cultural study. Applied Research on English Language, 2(2), 37-50.

Martin, James R. 1990. Literacy in science: Learning to handle text as technology. In: Frances Christie (ed.), Literacy for a Changing World. 79-117. Melbourne: Australian Council for Educational Research.

Martin, James R. 1993. Genre and literacy: Modelling context in educational linguistics. Annual Review of Applied Linguistics: Issues in Teaching and Learning, 13, 141-172.

Martin, James R. 2003. Beyond exchange: Appraisal systems in English. In: Susan Hunston and Geoff Thompson (eds.), Evaluation in Text: Authorial Stance and the Construction of Discourse, 142-177. Oxford: Oxford University Press.

Martin, James R., Christie, Frances and Joan Rothery. 1987. Social processes in education: A reply to Sawyer and Watson (and others). In: Ian Reid (ed.), The Place of Genre in Learning: Current Debates, 35-45. Geelong, Australia: Deakin University Press.

Motta-Roth, Désirée. 1998. Discourse analysis and academic book reviews: a study of text anddisciplinary cultures. In: Inmaculada Fortanet, Santiago Posteguillo, Juan C. Palmer and Juan. F. Coll (eds.), Genre Studies in English for Academic Purposes, 29-59. Castellón: Collecció Summa, Sèrie Filología/9.

Nwogu, Kevin N. 1997. The medical research paper: Structure and functions. English for Specific Purposes, 16(2), 119-38.

Paltridge, Brain. 1997. Genre, Frames, and Writing in Research Setting. Amsterdam: John Benjamins.

Römer, Ute. 2005. "This seems somewhat counterintuitive, though...": Negative evaluation in linguistic book reviews by male and female authors. In: Elena Tognini Bonelli and Gabriella Del Lungo Camiciotti (eds.), Strategies in Academic Discourse, 97-115. Amsterdam: John Benjamins.

Römer, Ute. 2008. Identification impossible? A corpus approach to realizations of evaluative meaning in academic writing. Functions of Language, 15(1), 115-130.

Salager-Meyer, Françoise and María Ángeles Alcaraz-Ariza. 2004. Las reseñas de libros en español: estudio retórico y diacrónico. Spanish in Context, 2(1), 29-49.

Samraj, Betty. 2005. An exploration of a genre set: Research article abstracts and introductions in two disciplines. English for Specific Purposes, 24(2), 141-156.

Schleppegrell, Mary J. 2001. Linguistic features of the language of schooling. Linguistics and Education, 12(4), 431-459.

Shaw, Philip. 2004. How do we recognize implicit evaluation in academic book reviews? In: Del Lungo Camiciotti and Elena Tognini-Bonelli (eds.), Academic Discourse: New Insights into Evaluation, 121-140. Bern: Peter Lang. 
Shaw, Philip. 2009. The lexis and grammar of explicit evaluation in academic book reviews? In: Ken Hyland and Giuliana Diani (eds.), Academic Evaluation: Review Genre in University Setting, 217-235. Houndmills: Palgrave Macmillan.

Simon-Vandenbergen, Anne-Marie, Taverniers, Miriam and Louise, J. Ravelli. 2003. Grammatical Metaphor: Views from Systemic Functional Linguistics. Amsterdam: John Benjamins.

Sorayyaei Azar, Ali. 2012. The self-promotion of academic textbooks in the preface section: A genre analysis. Journal of the Spanish Association of Anglo-American Studies, 34(2), 147-165.

Sušinskienè, Solvegia. 2009. Textual functions of nominalizations in English scientific discourse. Žmogus ir žodis, 11(3), 58-64.

Sušinskienè, Solvegia. 2010. Nominalization as a cohesive device in British newspaper editorials. Filologija, 15, 142-150.

Swales, John. M. 2004. Research Genres. Cambridge: Cambridge University Press.

Thompson, Geoffrey. 1994. Introducing functional grammar. London: Arnold.

Tse, Polly and Hyland, Ken. 2009. Gender and discipline: Exploring metadiscourse variation in academic book reviews. In: Ken Hyland and Marina Bondi (eds.), Academic Discourse across Disciplines, 177-202. Bern: Peter Lang.

Văn, Luan. 2011. A Study on Grammatical Metaphor in English Business Letters (M.A. Thesis). Hanoi: Vietnam National University.

Vassileva, Irena. 2010. Critical book reviews in German. International Journal of Applied Linguistics, 20(3), 354-367.

Wenyan, Gao. 2012. Nominalization in medical papers: A comparative study. Studies in Literature and Language, 4(1), 86-93.

Xue-feng, Wang. 2010. Grammatical metaphor and its difficulties in application. US-China Foreign Language, 8(12), 29-37.

Zepetnek, Steven T. D. 2010. Towards a taxonomy of the preface in English, French, and German. Neohelicon, 37(1), 75-90. 